\title{
Improve Critical Thinking Ability and Motivation in Learning Mathematics Through the Adobe Flash Cs 5.0 Game
}

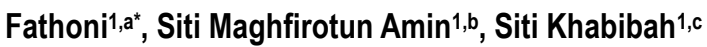 \\ ${ }^{1}$ Department of Mathematics Education, Postgraduate, State University of Surabaya, Surabaya, Indonesia \\ a fathoni16070785003@mhs.unesa.ac.id; b sitiamin@unesa.ac.id; \& c sitihabibah@unesa.ac.id; \\ ${ }^{*}$ Corresponding Author
}

How to Cite: Fathoni, F., Amin, S., M., Khabibah, S. (2019). Improve Critical Thinking Ability and Motivation in Learning Mathematics Through the Adobe Flash Cs 5.0 Game. International Journal for Educational and Vocational Studies, 1 (8), 869-872. DOI: https://doi.org/10.29103/ijevs.v1i8.2241

\section{ARTICLE HISTORY}

Received: 11 September 2019

Revised: 18 October 2019

Accepted: 4 November 2019

\section{KEYWORDS}

Critical Thinking Ability;

Motivation;

Adobe Flash CS 4;

\begin{abstract}
Mathematical learning needs to be given to all students starting from elementary school, so that students practice how to think in drawing conclusions and be able to express their opinions with the beliefs and honesty that comes from someone. But when learning mathematics the problem that often arises is a lack of motivation. Baroody (1993) says that reasoning is an important tool in learning mathematics to produce ideas so students can understand mathematical concepts correctly. Efforts made by teachers to improve thinking skills and motivation in learning mathematics are through the Adobe Flash CS 5.0 game which is expected to provide new and enjoyable experiences for teachers and students. In addition to more varied learning, students can be motivated to learn and enjoy what they learn.
\end{abstract}

This is an open access article under the CC-BY-SA license.

\section{INTRODUCTION}

Learning is a process of teaching and learning activities as well role in determining student learning success. From the learning process it will be a reciprocal activity between the teacher and students to towards a better destination. Therefore, the process of learning mathematics is right is very much needed so produce thinking ability and student motivation to increase. The purpose of learning mathematics is to train how to think and reasoned in drawing conclusions from problem solving with confidence and honesty. According to the National Council of Mathematics Teachers (NCTM) general objectives of students learning mathematics, namely; (1) learning values mathematics, understanding evolution, and its role in society and science, (2) confident in their abilities, believe in mathematical thinking owned and sensitive to situations and problems, (3) be a productive citizen and experienced in solving various problems, (4) learning to communicate mathematically, learning about symbols, symbols and mathematical methods, (5) learning to reason in a way mathematically, that is making guesses, proofs, and building arguments mathematically (Romberg in Hulu, 2009).

In conducting the mathematics learning process, the teacher must first understand that each student has unique and sustainable individual characteristics that develop including emotional, moral, intellectual and social development (Sunarto and Hartono, 2002: 181). then the teacher must prepare materials and learning methods that are appropriate to the ability of these students.

Multimedia learning methods through simple interactive presentation media is expected to provide new and enjoyable experiences for both teachers and students. In addition to more varied learning, students can be motivated to learn and enjoy what he learns. Currently the obstacle teachers teach students is designing products utilizing technology so that when teaching to students can be achieved, namely the teacher must be able and easy to use it and practical. One the multimedia used is Adobe Flash CS 5.0, because with using the software we can make mathematical games so students are more enthusiastic to learn.

In the research of Maria Virvou et al (Hidayatullah, 2011) about the effectiveness of the game in helping the learning process. They stated that the game was educational the virtual reality that they make (VR-ENGAGE) can be very motivating while enhance educative effects on students. What's interesting is that he told a deep story the paper that at the school where the 
research was, there used to be students which makes the classroom atmosphere less conducive. He often annoys his friend who is studying. But since the implementation of VR-ENGAGE, students never bothered his friend.

This game uses the help of electronic tools that are ICT-based games Adobe Flash CS 5.0 as a tool for creating games in it learning mathematics is more fun and students are also expected to do it give ideas and be able to appreciate in learning mathematics and can have great curiosity about appropriate technology. Learning models through Adobe Flash CS 5.0 Games can also bring up motivate students to be confident in using concepts mathematics, persistent and tenacious doing math, expressing his opinions and think logically and can make conclusions.

\section{METHODS}

This article is a literature study by examining journals related to improve ability of thinking and motivation in learning mathematics through the adobe flash cs 5.0 game. The results of various studies of this literature will be used to describe the problems of teacher performance related to culture and work environment.

\section{RESULTS AND DISCUSSIONS}

\subsection{Critical Thinking Ability}

According to Santrock (2011: 359), critical thinking is reflective and productive thinking, and involves evaluating evidence. Jensen (2011: 195) argues that critical thinking means process mentally effective and reliable, used in pursuit relevant and true knowledge about the world.

Wijaya (2010: 72) also expresses his ideas about ability critical thinking, namely the activity of analyzing ideas or ideas in the direction more specifically, distinguish them sharply, choose, identify, study and develop in the direction of the more perfect.

Scriven and Paul (1987) state, critical thinking is a process of intellectual discipline that actively and skillfully conceptualizes, applies, analyzes, synthesizes, and/or evaluates information collected from, or produced by, observations, experiences, reflections, reasoning, or communication, as a guide for beliefs and actions. In its exemplary form, it is based on universal intellectual values that go beyond the division of subject matter: clarity, accuracy, precision, consistency, relevance, strong evidence, good reason, depth, breadth, and fairness.

Critical thinking refers to higher-order thinking that questions assumptions and has been described as "thinking about thinking". We adopted the Watson-Glaser Critical Thinking Appraisal (WGCTA, Watson \& Glaser, 1980), one of the oldest and most widely used critical thinking steps, to assess students' critical thinking skills (Bernard, Zhang, Abrami, Sicoly, Borokhovski, \& Surkes, 2008 ; Pilcher \& Walters, 1997). Watson-Glaser Critical Thinking Appraisal (WGCTA) has five sub-domains: inference, introduction of assumptions, deduction, interpretation, and evaluation of arguments. According to Bernard et al. (2008), must be seen as a measure of general competence and that subscales must not be interpreted individually. Critical thinking leads people to beliefs and actions (Paul, 1993) and focuses on deciding what to believe or do and achieve goals.

Characteristics critical thinking includes: 1) good at detecting problems, 2) likes to collect data for factual verification; 3) able to interpret pictures or cartoons; 4) able to make interpretations understanding, definition, reason, and problem of controversy; 5) able to list all alternative possibilities or consequences solving problems, ideas, and situations; 6) able to be attractive conclusions from existing and selected data.

To be creative, an idea must also be appropriate-useful and actionable. Creativity has three major components: (1) expertise, (2) creative-thinking skills, and (3) motivation. Innovation depends on "creativity" which is the generation of those new and useful ideas. Encouragement of creativity, autonomy or freedom, and resources create stimulants to creativity, whereas pressures and organizational impediments to creativity are the obstacles. During downsizing, work environment stimulants to creativity decrease, while work environment obstacles increase (Amabile \& Conti, 1999). Having relatively unstructured, unpressured time to create and develop new ideas may lead to creativity. Time pressure undermines creativity. Intrinsic motivation promotes creativity. We discuss critical thinking skills from the perspectives of expertise, creative-thinking skills, and motivation below (cf. Amabile, 1998). Performance depends on one's ability (can do) and motivation (will do) in a given context (Bandura, 1986; Semerci, 2011). We turn to factors related to can do next.

\subsection{Motivation}

We turn to "within-subjects" changes and investigate factors that contribute to students' changes from the pre-test to the post-test. Since goals, values, and attitudes are related to creativity, motivation and learning styles may contribute to the improvement of their critical thinking skills (Rodriguez, 2009). Felder and Silverman (1988) studied students' different achievement goals for their academic pursuits (mastery-approach, performance-approach, mastery-avoidance, and performance-avoidance). Individuals with strong achievement motivation have high self-efficacy, and high performance (Tang \& Reynolds, 1993). Materialistic students have lower intrinsic mastery goals but higher extrinsic performance goals (Ku, Dittmar, \& Banerjee, 2012). Materialistic students, who (in the having mode) only "hear" and "memorize" words so that they can pass an exam, have lower performance, a year later.

According to Uno (2011: 23) learning motivation is internal and external encouragement to students who are studying for conduct behavior, generally with a few indicators or supporting elements. These indicators, between others: the desire and desire to succeed, 
encouragement and needs in learning, hopes and ideals of the future, deep appreciation learning, and a conducive learning environment.

Learning motivation is important for students and teachers. For students the importance of learning motivation is as follows: a) Resuscitation position at the beginning of learning, process, and final results; for example after a student reading a chapter from a reading book, compared to his classmates who also read this chapter; he is less successful catch the contents, then he was forced to read again. b) inform about the power of learning, compared to peers; as an illustration, if student learning efforts prove to be inadequate, c) direct the learning activities, as an illustration, after he knows that he hasn't studied seriously, proved to be a lot of jokes for example, then he will change his learning behavior. d) zoom in enthusiasm for learning, as an illustration, if he has spent learning funds and there are still younger siblings financed by parents, so he tries to be fast graduated, e) aware of the journey of learning and then work (between rest or play) continuous; individuals are trained to use their strengths such that it functions (Rooijakkers, 2006: 62).

Function motivation according to Hamalik (2011: 108) includes, a) Encourage the onset of behavior/an action, b) Motivation functions as a guide, meaning it leads to the act of achieving the desired goal, c) Motivation functions as a mobilizer, meaning as a motor activator in learning activities. While the important role learning motivation in learning, including: 1) motivation can play a role in strengthening learning when a person children are faced with a problem that is determine the solution and can only be solved thanks help with things you've been through. 2) the role of motivation in clarifying the learning objectives are closely related to the meaning of learning. children will be interested in learning something, if what is learned is at least already known or enjoyed its benefits by children. 3) motivation determines perseverance in learning. a child who has motivated to learn something trying to learn with good and persevering in the hope of getting better results.

Learning motivation can arise due to two kinds of factors affect it, namely: a) intrinsic motivation, which is the desire and desire to succeed and encouragement of learning needs, hopes for ideals, and b) extrinsic motivation is an appreciation, a learning environment conducive and interesting learning activities.

\subsection{Mathematics Learning Game Adobe Flash CS 5.0}

Adobe Flash is a graphic animation program that many used by designers to produce professional work, moreover in the field of animation. One of them is Adobe Flash CS5 (Adobe Flash Creative Suite5) which was released in 2010 by the AdobeSystem company incorporated, often used to create various animations such as Interactive animations, such as on web pages for aesthetic purposes, animation cartoons, presentations, portfolio of agencies, companies and individuals, games, and some animations.
Adobe Flash Creative Suite5 has several advantages with this version previous. Use such as TLF text is very helpful in managing text. Besides that students can also find the latest features on Flash CS5 (Creative Suite5), such as the Actionscript editor, integration with creative chains, integration with flash builder, enhancements for video, and fla-based files XML (Wahana Komputer 2011: 29). Facilities like 3D effects or Transformations are very interesting can be used to create interesting 3-dimensional animation effects. Adobe Flash CS5 (Adobe Flash Creative Suite5) is a refinement of the previous version was Adobe Flash CS4 (Pranowo 2011: 15).

Hidayatullah (2011:18) Steps in Mathematical Learning Games Macromedia Flash is, a) delivering goals and motivating students, in this step the learning objectives are conveyed with use flash games and provide motivation to students, b) study material, in this step, the teacher teaches the material presented in a flash game, c) divide the media, $\mathrm{n}$ this step the teacher starts to introduce the flash game media as a tool learning and teaching ways to use flash game media, d) guide, in this step the teacher helps each student individually, e) evaluation, the evaluation step aims to determine student learning outcomes from use of flash game media, and $\mathrm{f}$ ) appreciation, in this step the teacher gives a purposeful award motivate students in learning.

\section{CONCLUSION}

Not all games have a bad effect on students' brain development, because some games are designed to sharpen thinking so that they can have critical thinking and motivate children to be more creative in solving mathematical problems or tasks. It's just that for the intensity of its use may require parental knowledge so as not to become dependent on the game.

\section{REFERENCES}

Amabile, T. M. (1998). How to kill creativity. Harvard Business Review, 76 (5): 76-87.

Amabile, T. M., \& Conti, R. (1999). Changes in the work environment for creativity during downsizing. Academy of Management Journal, 42 (6): 630-640.

Bandura, A. (1986). Social foundations of thought and action: A social cognitive theory. Englewood Cliffs, NJ: Prentice Hall.

Barrody, A, J. (1993). Problem Solving, Reasoning, and Communicating, (K-8): Helping Children Think Mathematically. New York: Merill as imprint of Macmillan Publishing Company

Barnett, J. E., \& Francis, A. L.( 2012). Using Higher Order Thinking Questions to Foster Critical Thinking: A classroom study. Educational Psychology, 32 (2): 201-211.

Baron, J. B., \& Sternberg, R. J. (1987). Teaching thinking skills: Theory and Practice. New York: Freeman.

Bernard, R. M., Zhang, D., Abrami, P. C., Sicoly, F., 
Borokhovski, E., \& Surkes, M. A. (2008). Exploring the Structure of the Watson-Glaser Critical Thinking Appraisal: One scale or Many Subscales? Thinking Skills and Creativity, 3 (1): 15-22.

Bloom, B. S., Engelhart, M. D., Furst, E. J., Hill, W. H., \& Krathwohl, D. R. (1956). Taxonomy of Educational Objectives: The Classification of Educational Goals. Handbook I: Cognitive domain. New York: David McKay.

Butler, H. A. (2012). Halpern Critical Thinking Assessment Predicts Real-World Outcomes of Critical Thinking. Applied Cognitive Psychology, 26 (5): 721-729.

Felder, R. M., \& Silverman, L. K. (1988). Learning and teaching styles in engineering education. Engineering Education, 78 (7): 674-681

Hidayatullah, P., Daswanto, A., Nugroho .S.P. (2011) Making Mobile Games Educative with Flash. Bandung: Publisher Informatics.

Howard, L. W. (2008). Teaching Critical Thinking in the College of Business: A Manual for Developing and Implementing a Case-Based Critical Thinking Module. Unpublished manuscript, Middle Tennessee State University.

Ku, L., Dittmar, H., \& Banerjee, R. (2012). Are Materialistic Teenagers Less Motivated to learn? Cross-Sectional and Longitudinal Evidence from the United Kingdom and Hong Kong. Journal of Educational Psychology, 104 (1): 74-86.

NCTM. (1989). Curriculum and EvalutionStandards for School Mathematics.

Reston, Virginia: NCTM.INC.

NCTM [National Council of Teacher of Mathematics] (1991). Principles and Standrads for School Mathematucs. Reston Verginia: NCTM.INC

Podsakoff, P. M., Mac.Kenzie, S. B., Lee, J. Y., \& Podsakoff, N. P. (2003). Common Method Base in Behavioral Research: A Critical Review of the Literature and Recommended Remedies. Journal of Applied Psychology, 88: 879-903.

Pranowo, Galih. (2011). Interactive Animation Creations with Action Script 3.0 on Falsh CS5. Yogyakarta: Andi Offset

Rodriguez, C. M. (2009). The Impact of Academic Self-Concept, Expectations and the Choice of Learning Strategy on Academic Achievement: The Case of Business Students. Higher Education Research \& Development, 28 (5): 523-539.

Rooijakkers, Ad. (2006). Teaching with Success. Jakarta: PT. Gramedia

Scriven, M., \& Paul, R. (1987). The 8th Annual International Conference on Critical Thinking and Education Reform.
Semerci, C. (2011). The relationships between achievement focused motivation and critical thinking. African Journal of Business Management, 5 (15): 6180-6185.

Tang, T. L. P., \& Reynolds, D. B. (1993). Effects of self-esteem and perceived goal difficulty on goal setting, certainty, task performance, and attributions. Human Resource Development Quarterly, 4: 153-170.

Uno, B Hamzah. (2011). Motivation Theory and Measurement. Jakarta: Earth Literacy

Watson, G., \& Glaser, E. M. (1980). Watson-Glaser critical thinking appraisal manual. New York: The Psychological Corporation. 